\title{
ナギナタガヤ草生ミカン園における春肥窒素の吸収特性
}

\author{
石川 啓 $1 *$ * 木村秀也 ${ }^{2}$ \\ 1 愛媛県立果樹試験場 791-0112 松山市下伊台町 1618 \\ 2 近畿中国四国農業研究センター 721-8514 福山市西深津町 6-12-1
}

\section{Absorption of Spring Applied Nitrogen in Satsuma Mandarin Orchard Covered with Rat's-tail Fescue, Vulpia myuros}

\author{
Kei Ishikawa ${ }^{1 *}$ and Hideya Kimura ${ }^{2}$ \\ ${ }^{1}$ Ehime Fruit Tree Experiment Station, Shimoidai, Matsuyama, Ehime 791-0112 \\ ${ }^{2}$ National Agricultural Research Center for Western Region, Nishifukatsu, Fukuyama, Hiroshima 721-8514
}

\begin{abstract}
A ${ }^{15} \mathrm{~N}$-tracer method was used to study the absorption of nitrogen applied in the spring to Satsuma mandarin trees and Rat'stail fescue, Vulpia myuros, in a mandarin orange orchard covered with Rat's-tail fescue. The amount of nitrogen applied in the spring that was absorbed by mandarin orange trees in a plot covered with Rat's-tail fescue was markedly smaller, about $47 \%$, than that in a clean cultivated plot; the difference was particularly large in new leaves. The amount of nitrogen absorbed by Rat's-tail fescue in a sod culture plot was about twice as large as that absorbed by the trees in the plot. Trees in the clean cultivated plot showed higher rates of ${ }^{15} \mathrm{~N}$ occupied by supplied nitrogen in all organs than trees in the sod culture plot did; the difference was particularly large in newly developed organs. However, Rat's-tail fescue in the sod culture plot showed a markedly higher rate of ${ }^{15} \mathrm{~N}$ occupied by supplied nitrogen than the trees showed. A comparison of the utilization rates of nitrogen applied in the spring to trees in two different plots demonstrated that the rate was $16.7 \%$ in the sod culture plot and $35.3 \%$ in the clean cultivated plot; the rate was markedly higher in the clean cultivated plot. However, the utilization rate including an absorbed amount by Rat's-tail fescue was $51.6 \%$ in the sod culture plot, which was about 1.5 times as high as that in the clean cultivated plot.
\end{abstract}

Key Words : ${ }^{15} \mathrm{~N}$-tracer method, Satsuma mandarin, Sod culture

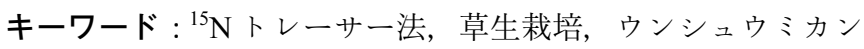

\section{緒言}

果樹園に沶ける草生栽培に関する研究については, 既に 多くの報告があり，これらの中には草生による土㙋環境の 変化，草生が樹体や収量・果実品質等に及ぼす影響を長期間 にわたり詳細に検討した事例（笠原・渡辺，1982; 坂本ら， 1965; 高辻ら，1987; 渡辺・笠原，1982; 渡辺，1968）为 久ら れる. しかし, カンキッ園の草生条件下に打施肥窒素の 樹体や草種による吸収特性について, 定量的な手法で検討し た研究例は極めて少なく，不明な点が多く残されている.

また近年, カンキッ園では雑草管理の省力化や土畩改良 効果を期待して，ナギナタガヤを利用した草生栽培が急速 に普及し始めている. ナギナタガヤは 1 年生のイネ科草種 であり（長田, 1989), 秋季に発芽し, 春季に旺盛な生育を 示して出穂後は自重で自然に倒伏し，初夏に枯死する。こ

2005 年 10 月 3 日 受付. 2005 年 12 月 1 日 受理.

本報告の一部は園芸学会中四国支部平成 14 年度大会で発表した

* Corresponding author. E-mail: ishikawa-kei@pref.ehime.jp
のため, 刈り払ら必要が無く，乙かも枯死後は敷き草状態 となり地表面を被覆するため夏草の発生を抑制することが 可能である，一方，このナギナタガヤ草生栽培は，雑草管 理以外にも，社会的な問題となっている施肥窒素の溶脱に 起因する環境負荷の軽減策の一つとして注目されている. すなわち，樹体に加えナギナタガヤによる施肥窒素の吸収 を利用し，園全体としての窒素利用率の向上を図ることが 可能となれば，溶脱窒素量は減少することが期待できる. しかし, 実際に本種をミカン園に導入した際の施肥窒素の 吸収量, あるいはミカン樹との窒素競合関係等については, 末だ明らかにされていない。

これらのことから，筆者らはナギナタガヤの生育盛期に 施用される春肥窒素のウンシュウミカンおよびナギナタガ ヤによる吸収特性について, ポット栽培条件下において ${ }^{15} \mathrm{~N}$ トレーサー法を用いて検討した。

\section{材料および方法}

愛媛県立果樹試験場内において容積約 $60 \mathrm{~L}$ の黒色ポット (上面半径約 $24 \mathrm{~cm}$, 下面半径約 $21 \mathrm{~cm}$, 高さ約 $40 \mathrm{~cm}$ の逆 
円錐台形）に植栽されている 3 年生“南相 20 号”を 3 ポッ 卜／区供試し，ナギナタガヤ草生区（以下草生区）抒よび 清耕裸地区（以下裸地区）を設けた。草生区については, 生育初期のナギナタガヤによる秋肥窒素の吸収に伴う樹体 への影響を避けるため, 別の圃場において 2000 年 10 月中 旬に播種し (播種量 : 約 $8 \mathrm{~kg} / 10 \mathrm{a}$ 換算量・雪印種苗社製の 種子), 育成していたナギナタガヤを 2001 年 2 月にポット に移植した.なお, ポットの土畩は, 2000 年 3 月の苗木植 光付け時に花崗岩質土壤（中粗粒褐色森林土，約 $50 \mathrm{~L} / \mathrm{pot}$ ) と牛粪オガクズ堆肥(約 $10 \mathrm{~L} / \mathrm{pot}$ )を混合したものを用いた.

供試肥料として ${ }^{15} \mathrm{~N}$ 標識硫安（10.3 atom\%）を用い， N : $10 \mathrm{~kg} / 10 \mathrm{a}$ 換算量 $(8.18 \mathrm{~g} / \mathrm{pot})$ を $2 \mathrm{~L}$ の水に溶かし, 2001 年 3 月 14 日に施用した. リン酸打よび加里は, 過燐酸石灰 （7.93 g/pot） と硫酸加里（3.08 g/pot）を施用した.

供試ポットは, 施肥前までは露地栽培を行い, 施肥後は 側面を解放したガラス室内に移し，解体時まで管理した. 灌水は施肥後〜解体時まで $4 \sim 5$ 日間隔 $(6 \sim 9 \mathrm{~mm} /$ 回 $)$
で実施した。

解体は，2001 年 6 月 6 日〜 11 日にかけて樹体を新葉・ 新梢・幼果・旧葉・ 1 年枝 $\cdot 2$ 年枝・主幹・細根・ 小中根・ 大根根幹に分けて実施した。 また，施肥時から解体時まで 旧葉や花器等の落下物を適宜採取した。ナギナタガヤは倒 伏した穂部からの種子の脱落を防ぐため地上部を 5 月 31 日 に刈り取り，地下部は樹体の解体時に採取した。

調査は, 解体時に旧葉と新葉の着生数を測定するととも に, 樹体抢よびナギナタガヤ各器官の乾物重, 全窒素含有 率执よび ${ }^{15} \mathrm{~N}$ 濃度について行った．全窒素分析はケルダー 儿法, ${ }^{15} \mathrm{~N}$ 分析は狩野ら（1974）の方法に準じて発光分析法 （日本分光社製 N-151 アナライザー）により実施した.

\section{結果}

樹体の乾物重は, 総量では草生区の方が裸地区より $11 \%$ 程度少なかった，これを器官別にみると，特に新葉に拈け る差異が大きく, 裸地区の $50 \%$ 以下であった(第 1 表)。ま

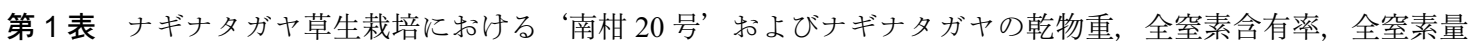

\begin{tabular}{|c|c|c|c|c|c|c|}
\hline \multirow[t]{2}{*}{ 部 位 } & \multicolumn{2}{|c|}{ 乾物重（g/pot $\left.{ }^{\mathrm{y}}\right)$} & \multicolumn{2}{|c|}{ 全 $\mathrm{N}$ 含有率（\%） } & \multicolumn{2}{|c|}{ 全 $\mathrm{N}$ 量（g/pot $\left.{ }^{\mathrm{y}}\right)$} \\
\hline & 草生区 & 裸地区 & 草生区 & 裸地区 & 草生区 & 裸地区 \\
\hline 体） & & & & & & \\
\hline 新＼cjkstart葉 & 21.1 & $45.0^{* z}$ & 2.74 & 2.97 & 0.59 & $1.34^{*}$ \\
\hline 梢 & 4.3 & 6.1 & 2.40 & 2.19 & 0.11 & 0.13 \\
\hline 幼 & 12.0 & 15.7 & 2.47 & 2.42 & 0.30 & 0.38 \\
\hline 旧葉 & 60.1 & 62.0 & 2.45 & 2.48 & 1.46 & 1.51 \\
\hline 1 年 枝 & 32.7 & $36.8^{*}$ & 1.29 & 1.42 & 0.42 & $0.52^{*}$ \\
\hline 2 年 枝 & 49.4 & 58.6 & 0.75 & 0.81 & 0.37 & 0.46 \\
\hline 主 幹 & 37.4 & 37.6 & 0.60 & 0.64 & 0.23 & 0.24 \\
\hline 細 根 & 87.6 & 91.8 & 1.95 & 2.08 & 1.67 & 1.88 \\
\hline 小中 根 & 35.6 & 41.8 & 1.31 & 1.18 & 0.46 & 0.48 \\
\hline 大根根幹 & 59.2 & 50.7 & 0.87 & 0.76 & 0.51 & 0.39 \\
\hline 落下旧葉 & 22.3 & 23.4 & 2.27 & 2.42 & 0.50 & 0.57 \\
\hline 落花（果） & 31.5 & 40.2 & 3.48 & 3.65 & 1.09 & 1.47 \\
\hline 樹 全 体 & 453.1 & 509.6 & 1.70 & $1.84^{*}$ & 7.70 & $9.36^{*}$ \\
\hline \multicolumn{7}{|l|}{ (ナギナタガヤ) } \\
\hline 茎葉・穂 & 91.9 & - & 1.58 & - & 1.45 & - \\
\hline 根 & 16.4 & - & 1.19 & - & 0.20 & - \\
\hline ナギナタガヤ全体 & 108.3 & - & 1.52 & - & 1.65 & - \\
\hline 合計 & 561.4 & 509.6 & - & - & 9.35 & 9.36 \\
\hline
\end{tabular}

$\mathrm{z} *: \mathrm{T}$ 検定において 5\%レベルで有意差があることを示す $(\mathrm{n}=3)$

$\mathrm{y}$ 容積約 $60 \mathrm{~L}$ の pot

第 2 表 ナギナタガヤ草生栽培が ‘南柑 20 号’の旧葉抢よび新葉に及ぼす影響

\begin{tabular}{|c|c|c|c|c|c|}
\hline \multirow{2}{*}{\multicolumn{2}{|c|}{ 試 験 区 }} & \multicolumn{2}{|c|}{ 旧 葉 } & \multicolumn{2}{|c|}{ 新 葉 } \\
\hline & & 着葉数 ${ }^{y}$ & $\begin{array}{c}1 \text { 葉重 } \\
(\mathrm{mg} \mathrm{DW})\end{array}$ & 着葉数 ${ }^{y}$ & $\begin{array}{c}1 \text { 葉重 } \\
(\mathrm{mg} \mathrm{DW})\end{array}$ \\
\hline & 生 区 & 326.3 & 178.7 & 500.0 & 41.8 \\
\hline & 地 区 & 320.0 & 184.1 & 743.7 & 62.9 \\
\hline 有 & 意 性 ${ }^{\mathrm{z}}$ & NS & NS & $*$ & NS \\
\hline
\end{tabular}

$\mathrm{z} * \mathrm{~T}$ 検定において 5\%レベルで有意差があることを示す $(\mathrm{n}=3)$

$\mathrm{y}$ 解体時の着生葉, 1 pot 平均値 


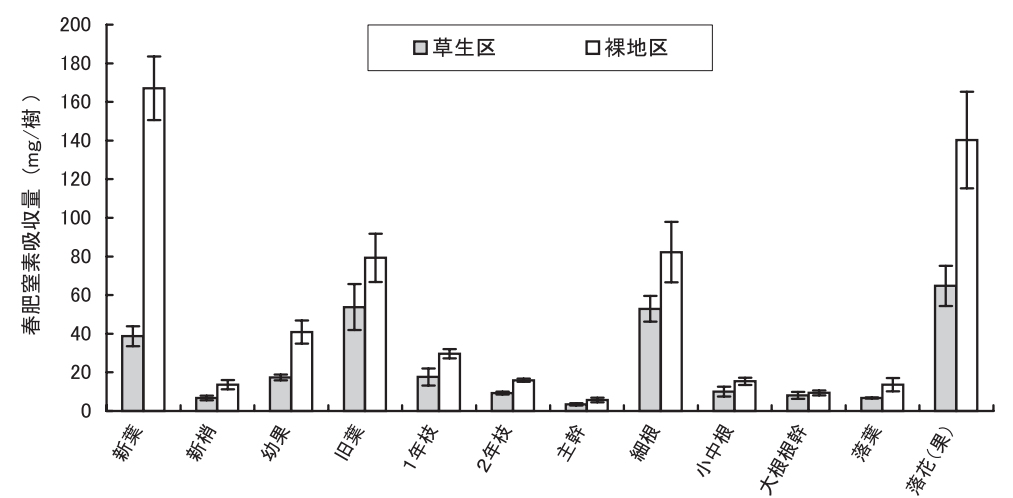

第 1 図 ナギナタガヤ草生区扣よび裸地区に打ける “南柑 20 号’ の 器官別春肥窒素吸収量 誤差線は標準誤差を示す（n=3）

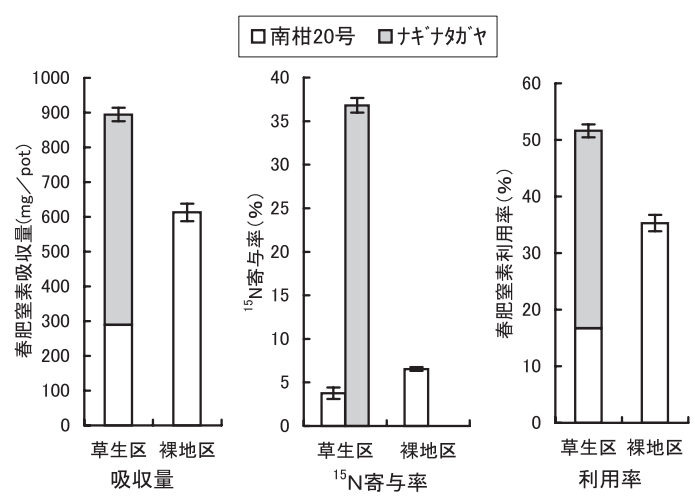

第 2 図 ナギナタガヤ草生区と裸地区の春肥窒素吸 収量・利用率执よび ${ }^{15} \mathrm{~N}$ 寄与率 誤差線は標準誤差を示す $(n=3)$

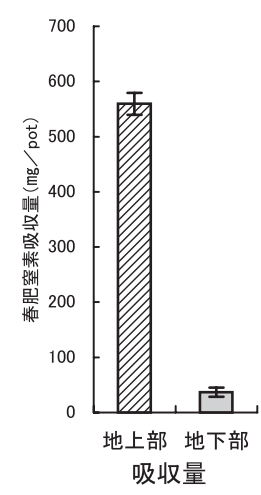

第 3 図 ナギナタガヤの春肥窒素吸収 量扣よび ${ }^{15} \mathrm{~N}$ 寄与率

䛊差線は標準䛊差を示す $(n=3)$

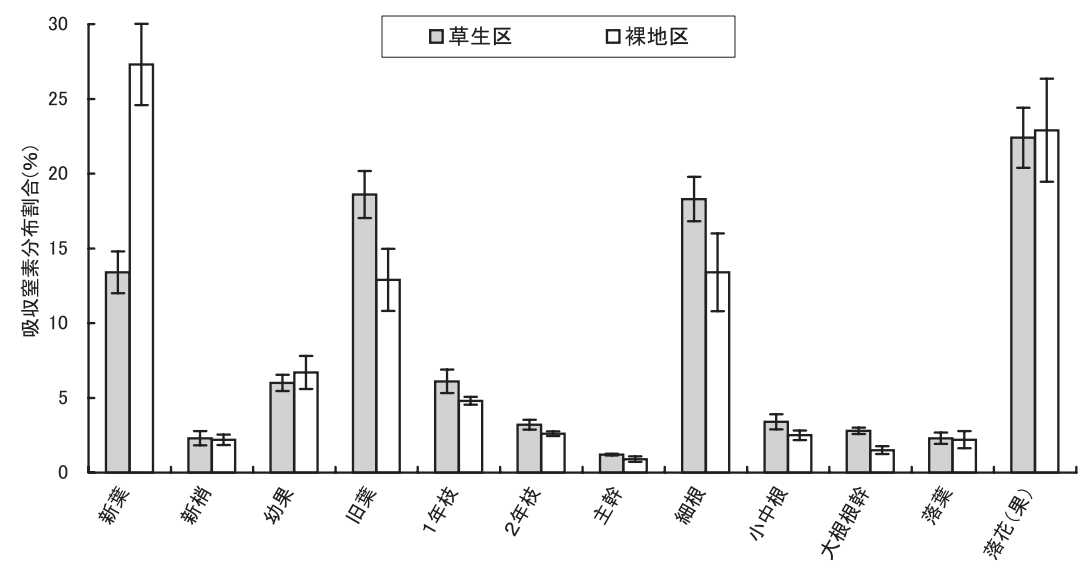

第 4 図 ナギナタガヤ草生区括よび裸地区に打ける “南柑 20 号” の器官別吸収窒 素分布割合 誤差線は標準誤差を示す $(n=3)$
た，草生区では新葉の着生数が減少し，1 葉重も裸地区の 66\%程度であった (第 2 表).ナギナタガヤの乾物重は樹体 の $24 \%$ 程度と少なかった。 ナギナタガヤは地上部の割合 が高く, 全体の $85 \%$ 程度であった（第 1 表）。樹体の全窒 素含有率は, 草生区では新葉, 1 年枝, 2 年枝, 細根などに 扣いて裸地区ょり低い傾向にあったが，有意な差ではな かった。 また，全窒素量についてみると，樹体では新葉お よび 1 年枝に沶いて，草生区の方が裸地区ょり有意に少な かった．総量でも草生区の方が $18 \%$ 程度少なかった，一 方, ナギナタガヤの全窒素量は樹体の $21 \%$ 程度であった (第 1 表).

トレーサーにより求められた春肥窒素の吸収量は, 樹体 では草生区が裸地区の約 47\%であり著しく少なかった. 器 官別に比較すると, 新葉に打ける差異が最も大きく, 次い で落花 (果), 幼果, 新梢の順となった (第 1 図). 草生区 に打けるナギナタガヤの吸収量は, 樹体の約 2 倍であった (第 2 図)。また, ナギナタガヤでは地上部による吸収量が 著しく多かった（第 3 図）.
樹体内に打ける吸収窒素の分布割合は, 両区とも新葉, 旧葉，細根，落花（果）などで高かった。 これらの器官に ついて比較すると，草生区は裸地区に比べ新葉に打いて低 く，旧葉・細根ではやや高い傾向がみられた（第 4 図）.

${ }^{15} \mathrm{~N}$ 寄与率（赤尾ら，1978）（その器官に存在する総ての 窒素のらち施肥窒素の占める割合）は，両区に共通する傾 向として, 新葉, 新梢, 幼果, 落花（果）などの新生器官 が，他の器官に比べてかなり高率であった。草生区と裸地 区を比較すると，いずれの器官に执いても裸地区の方が有 意に高く，特に新生器官に打ける差異が大きかった（第 5 図)。一方，ナギナタガヤに打将 ${ }^{15} \mathrm{~N}$ 寄与率は，樹体に比 べ著しく高かった（第 2 図）.

春肥窒素の利用率（施用窒素総量に対する吸収窒素の割 合）は，樹体で比較すると草生区 $16.7 \%$ ，裸地区 35.3\%で あり，裸地区の方が顕著に高かった。 しかし，ナギナタガ ヤによる吸収量を加えた草生区の利用率は $51.6 \%$ となり, 裸地区の約 1.5 倍であった（第 2 図）. 


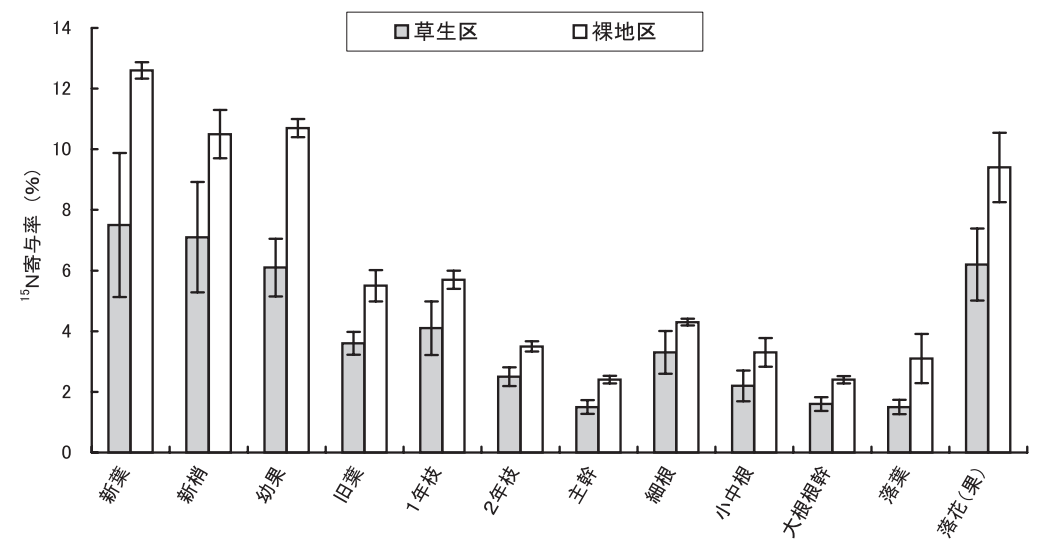

第 5 図 ナギナタガヤ草生区拉よび裸地区に打ける ‘南柑 20 号’ の器官別 ${ }^{15} \mathrm{~N}$ 寄与率 䛊差線は標準誤差を示す $(n=3)$

\section{考察}

ナギナタガヤの愛媛県における発芽期は概ね 10 月上旬頃 であり, 5 15 cm 程度の草高で越冬する. 気温が上昇し始 める 3 月上旬頃から伸長を再開し， 3 月下旬〜 4 月下旬頃 には草高 $60 \mathrm{~cm}$ 程に達し生育盛期を迎え, 出穂後倒伏して 5 月中下旬頃に枯死する. ウンシュウミカンの春肥は一般に 3 月に施用されるため, 寒地型草種であるナギナタガヤを導 入した園地では, 施用後の春肥はミカン樹と生育盛期に当 たるナギナタガヤの双方に吸収されることが推測された.

草生区のナギナタガヤによる春肥窒素の吸収についてみ ると, その利用率は $34.9 \%$ と高く, 裸地区の樹体による利用 率に匹敵する程であった。 同じイネ科で寒地型草種のオー チャードグラスをリンゴ園に供試した佐藤・佐々木（1982） は，4月上旬に施肥を行った場合，5月中旬に実施した 1 回 目の刈り取りまでの間に，オーチャードグラスが年間に吸 収した施肥由来窒素の約 $74 \%$ もの量が吸収されたことを明 らかにしている. 本試験の春肥施用時に抢けるナギナタガ ヤの草丈は $10 \sim 15 \mathrm{~cm}$ 程度であったが, 生育盛期の 4 月中 下旬頃には $45 \sim 55 \mathrm{~cm}$ にまで伸長していたことから，オー チャードグラスと同様に施肥後から約 40 日の間に旺盛な生 長に伴ら急激な窒素吸収が行われたものと考兄られた。

ナギナタガヤに打ける春肥吸収窒素の分布割合は, 茎葉 部と穂部を合わせた地上部が約 94\%であり, 地下部が約 6 $\%$ と地上部に偏在していた。 ${ }^{15} \mathrm{~N}$ 寄与率についても地上部 約 40\%, 地下部約 19\%であったことから，この時期にナギ ナタガヤが吸収した春肥窒素の大部分は地上部の生育に利 用されていることが示された. また, 本試験の草生区に拉 けるナギナタガヤの乾物重は, $10 \mathrm{a}$ 当たりに換算すると約 $625 \mathrm{~kg}$ であり, 発芽から枯死までに吸収した全窒素量は約 $9.5 \mathrm{~kg} / 10 \mathrm{a}$ であった。 このらち春肥窒素由来分は約 $3.5 \mathrm{~kg} /$ $10 \mathrm{a}$ であったことから, 残量の約 $6.0 \mathrm{~kg} / 10 \mathrm{a}$ については他時 期の施肥窒素由来分, あるいは地力窒素に由来するものと 考えられた.
草生区の樹体 “南柑 20 号’による春肥窒素の吸収につい てみると，その利用率は16.7\%であり，裸地区に拉ける樹 体の吸収量の約 $47 \%$ と低率であった。 これは, ナギナタガ ヤによる施肥窒素吸収（収奪）の影響によるものと容易に 推測され， $3 \sim 4$ 年生のリンゴ樹を供試した佐藤・佐々木 （1982）も, 清耕区に比べオーチャードグラス草生区のリン ゴ樹による利用率が著しく低いことを報告して扣り，本試 験結果と一致する.ナギナタガヤの乾物重は樹体の約 $24 \%$ であり，全窒素量も約 $21 \%$ と少なかったにも関わらず，施 肥窒素の吸収量は樹体の約 2 倍であった. 早春季の草によ る窒素吸収については，寒地型のイネ科牧草による窒素の 「先取り」が指摘されて扣り（佐藤・佐々木，1982），ナギ ナタガヤの場合もその生育パターンから，樹体よりも早期 から旺盛な窒素吸収が行われているものと考えられる.

草生区と裸地区の樹体に扣ける春肥窒素吸収量扎よび ${ }^{15} \mathrm{~N}$ 寄与率を比較すると, その差は春季新生器官, 特に新葉 に颃いて大きかった。この結果は, 新生器官への集積が多 い春肥由来窒素の吸収・移行特性（久保田ら，1976）から 容易に理解できる事象であり，このことが草生区の樹体に 及湆す影響として，新葉の乾物重の減少抏よび全窒素含有 率の低下が認められた。 これは, 新葉着生数扣よび 1 葉重 の減少によるものであり, 春肥窒素の吸収不足に伴う新葉 への移行量減少に起因するものと考兄られた。

草生栽培が樹体の生育に及ぼす影響については, ウン シュウミカン（江ロら, 1959; 渡辺, 1968; 山崎, 1987), リン ゴ（森・定盛，1955; 佐藤・佐々木，1982; 涉川ら，1952）の 事例から，特に幼木期や草種導入当初，あるいは干ばつな ぞの異常気象時に拈いて, 草との養水分競合から窒素レべ ルや樹勢の低下, 生育不良や収量の減少が認められること が多い. 本試験に打けるナギナタガヤ草生栽培に打いても, 前述のよらな窒素レベルの低下に伴ら新葉数の減少が示さ れたことから，特に導入当初の幼木などでは春季の窒素補 給対策を講じる必要がある。一方で, 草生栽培の継続は多 くの場合, 顕著な土壌改良効果をもたらし（笠原・渡辺, 
1982; 坂本ら，1965; 渡辺，1968），長期の草生栽培によっ て樹体生育が旺盛になり, 収量が増加した例 (坂本ら, 1965; 渡辺・笠原, 1982; 渡辺, 1968）も及られる.ナギナタガ ヤの場合も, 草生の継続によってこらした効果が期待され, また，生育パターンから想定すると夏肥窒素の競合は活と んぞ無く, 夏季は敷き草状態になっているため, むしろ樹 体による吸収率が高まる可能性があると推測される。

春肥窒素の利用率を園全体として比較すると, 草生区は ナギナタガヤと樹体による吸収量の加算値となるため 51.6 \%であり, 裸地区の $35.3 \%$ に比べ高率となった. これを $10 \mathrm{a}$ 当たりに換算すると, 草生区の春肥窒素吸収量は約 $5.2 \mathrm{~kg} /$ $10 \mathrm{a}$, 裸地区は約 $3.5 \mathrm{~kg} / 10 \mathrm{a}$ となり, 草生区の方が $1.7 \mathrm{~kg} / 10 \mathrm{a}$ 程多くなることが確認され, 両区ともに吸収されなかった 残量は溶脱あるいは土壤残存するものと考兄られた．ライ シメーターを用いて草生栽培と裸地栽培の窒素溶脱を検討 した坂本（1963）打よび山崎（1981）は，草生によって溶 脱窒素量が減少することを報告して扔り, 本試験に打いて も春肥窒素の残量は草生区の方が明らかに少なかったこと から，ナギナタガヤの導入は環境負荷軽減に寄与できるも のと推察される.

以上の結果から, ウンシュウミカン園へのナギナタガヤ の導入は, 園全体での春肥窒素の吸収量を増加させること が明らかになった。 しかし，ナギナタガヤによる吸収量は 樹体に比べかなり多いため, 特に貯蔵窒素の少ない幼木園 なぞに導入した当初は，樹体への窒素補給対策を講じるこ とが望ましく，その方法についてはさらに検討を要する。

\section{摘 要}

ナギナタガヤ草生ミカン園に抢ける, 春肥窒素のウン シュウミカン樹とナギナタガヤによる吸收特性を把握する ため, $60 \mathrm{~L}$ ポット植え “南柑 20 号”を供試し, ${ }^{15} \mathrm{~N}$ トレーサー 法を用いて検討した.

草生区の樹体は裸地区に比べ，新葉の着生数が減少し， 乾物重扮よび全窒素量も少なかった。ナギナタガヤの乾物 重は樹体の $24 \%$ 程度であった。樹体の春肥窒素吸収量は, 草生区が裸地区の約 $47 \%$ と著しく少なく, 特に新葉におけ る差異が大きかった，草生区におけるナギナタガヤの吸収 量は, 樹体の約 2 倍であった。 また, ナギナタガヤは吸収 窒素の大部分が地上部に分配されていた. 樹体の ${ }^{15} \mathrm{~N}$ 寄与 率は, いずれの器官に扔いても裸地区の方が高く, 特に新 生器官に打ける差異が大きかった. 一方, ナギナタガヤに 扣ける ${ }^{15} \mathrm{~N}$ 寄与率は, 樹体に比べ著しく高かった. 春肥窒 素の利用率は, 樹体を比較すると草生区 $16.7 \%$, 裸地区 35.3\%であり, 裸地区の方が顕著に高かった. しかし，ナ ギナタガヤによる吸収量を加えた草生区の利用率は $51.6 \%$ となり，裸地区の約 1.5 倍であった.

\section{引用文献}

赤尾勝一郎・久保田收治・林田至人. 1978. 温州ミカン樹の
春季新生器官形成時における樹体内貯蔵窒素, 特に秋 肥窒素の利用について (その 1). 園学雑. 47:31-38.

江口 浩・江口英信・高木義昭. 1959. 温州及かんの草生 栽培に関する研究（第 1 報）草生植物の根群及び温州 久かん幼木の生育について. 佐賀県農試果樹分場研報. 2: $1-16$.

狩野広美 - 米山忠克 - 熊沢喜久雄. 1974. 発光分光分析法 による重窒素の定量について。.土肥誌. 45: 549-559.

笠原敏夫・渡辺信吾. 1982. 砂丘地に打任るモ園の草生 栽培に関する研究（第 2 報）土壌の理化学性に及ぼす 影響. 新潟園試研報. 11: 15-29.

久保田収治・加藤忠司・赤尾勝一郎・文屋千代. 1976. 重 窒素利用による，温州ミカンの窒素の吸收とその体内 移行に関寸る研究（第 3 報）早春肥窒素について。四 国農試報. 29: 49-53.

森 英男・定盛昌助. 1955. りんご園の草生栽培に関する 試験（第 1 報）樹体とクローバー草生の土壌養水分の 競合. 東北農試研報. 4: 106-124.

長田武正. 1989. 日本イネ科植物図譜. p. 136-141. 平凡社. 東京.

坂本辰馬. 1963. 温州ミカンの土㙵ならびにその管理に関 する研究. 愛媛果試研報. 3:24-36.

坂本辰馬 - 奥地 進 - 円木忠志 - 船上和喜. 1965. 温州 ミ カン園に扔ける各種土㙥管理法の 10 年間の比較. 園学 雑. 34: 277-285.

佐藤雄夫・佐々木生雄. 1982. リンゴ園の窒素施肥に関する 試験(第 2 報) リンゴ樹の窒素吸收に対する草生抒よび 敷草の影響. 福島果試研報. 10: 23-33.

涉川潤一・細貝節夫・相馬盛雄・江渡達男. 1952. りんご 園の草生栽培に関する研究（第 2 報）草生りんご園の 諸調查. 園学雑. 21: 225-235.

高辻豊二・犬塚和男・後田経雄. 1987. 土袞表面管理法が 草生ミカンの樹体栄養と収量に及洁す影響. 九農研. 49: 109.

渡辺信吾・笠原敏夫. 1982. 砂丘地に打けるモモ園の草生 栽培に関する研究（第 1 報）モモ樹の成長，収量，果 実品質に及洔す影響. 新潟園試研報. 11:1-13.

渡辺登志彦. 1968. 瀬戸内カンキッ園の土㙵管理に関する 研究（第 1 報）各種土壌管理法が土壤の理化学性抢よ びカンキッの発育, 収量におよぼす影響。広島県農試 報告. 28: 1-15.

山崎隆生. 1981. ミカン園土㙵の養分収支に関する研究 （第 1 報）地質母材，施肥量及び土㙥管理法が浸透水量 及び肥料成分の浸出量に及洔影響. 広島県果樹試研 報. 7: 9-17.

山崎隆生. 1987. ミカン園土袞の養分収支に関する研究 （第 2 報）地質母材，施肥量及び土壌管理法の違いが 果実の收量及び品質に及ぼす影響. 広島県果樹試研 報. 12: 39-46. 